\title{
The Relationship between E-Marketing Strategy and Competitive Advantage: A Conceptual Framework
}

\author{
Azahari Jamaludin ${ }^{1 *}$, Mohd Hanafia Huridi², Yasmin Jamaludin ${ }^{1}$ \\ ${ }^{1}$ Geomatika University College, Kuala Lumpur, Malaysia \\ ${ }^{2}$ Universiti Kuala Lumpur, Kuala Lumpur, Malaysia
}

*Corresponding Author: Azahari Jamaludin, Geomatika University College, Kuala Lumpur, Malaysia

\begin{abstract}
Current research tries to offer some valuable insight into the relationship between E-marketing strategy and competitive advantage. This is done by exploring whether the acceptance of e-marketing strategy really impacts the competitive advantage of businesses. Grounded on the literature reviews, the researchers underlined and deliberated the imperative components contributing to the success of E-marketing. Here, the researchers depict the E-marketing mix using a $(4 P s+3 P s)+S 3 P 2 C 2$. Whereby the researchers preserve the original 4Ps (Product, Price, Place, and Promotion) plus additional 3Ps (Physical Environment, Process and People) and added Site Design, Security, Sales Promotion, Personalization, Privacy, Customer Service, and Community to define the E-marketing mix. The study recommended that any newly set-up and existing businesses should study and examine the e-marketing mix elements before making any commitment in any type business models.
\end{abstract}

Keywords: Marketing, E-Marketing, Online-Marketing and Competitive Advantage

\section{INTRODUCTION}

The popular marketing mix has been in existence for more than 40 years as the 4Ps (Product, Price, Place, and Promotion) (Kotler \& Armstrong, 2010; Kalyanam \& McIntyre, 2002). It was first introduced by McCarthy in 1960 and consists of 12 factors. Eventually the 12 factors have been reduced or combined to the much smaller number of 4 , thus became simpler and easier to comprehend. However, there were several significant components were missed out such as the service provision to the customer. Any service provision and the role of good customer service were largely ignored. Therefore, the impending effect on brand improvement and the customer experience was not understood. This was resolved when Booms and Bitner recommended their extension to produce the services marketing mix that we see today. The extended model should now be used to craft competitive strategies in a more holistic way (Martin, 2014).

Furthermore, in the post dot-com boom era, marketers and leaders are learning to cope with the entire new marketing components that have developed from the Internet. In some ways these new marketing components have close similarities in the off-line world. And yet from another standpoint they are innovative and worthy of a new characterization into what we coin as the E-Marketing mix. Today, only a very small number of business plans can be completed without taking into consideration the EMarketing mix into the traditional marketing mix to form an effective business tactic (Kalyanam \& McIntyre, 2002).

\section{E-MARKETING ELEMENTS}

Here, the researchers describe the E-Marketing Mix using a (4Ps + 3Ps) + S3P2C2. In other words we retain the unique 4Ps (Product, Price, Place, and Promotion) plus additional 3Ps (Physical Environment, Process and People)and added Site Design, Security, Sales Promotion, Personalization, Privacy, Customer Service, and Community to illustrate the E-Marketing Mix (see Figure 1) (Azahari, Raemah\& Yasmin, 2013; Kalyanam\& McIntyre, 2002).

According to the United States Department of Commerce (1996), approximately about 23 percent of small enterprises proceed to their fifth year. A business does not guarantee a success to its owner as far as business success is concerned. Nevertheless, a successful business depends on numerous 
internal and external elements. Among the most acutecomponents contributing to the success of business depends mainly on the following e-marketing components as depicted in Figure 1 (Azahari, Raemah\& Yasmin, 2013; Azahari \& Abd. Razak, 2010; Kalyanam\& McIntyre, 2002).

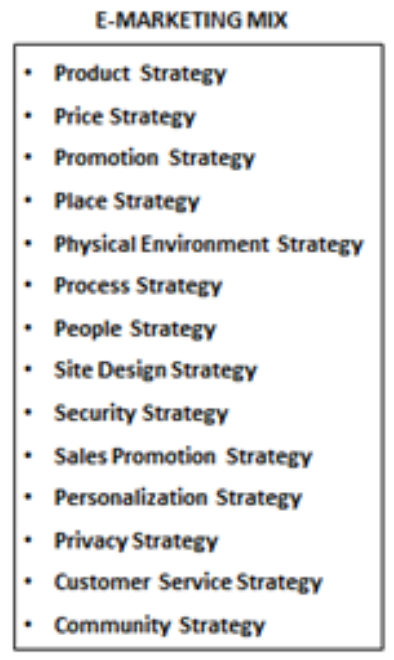

Figure1. The E-Marketing Mix

\subsection{Product Strategy}

The E-Marketing mix has many similarities to the variety selection practices of merchants. Therefore, we only concentrate on some of the distinctive abilities in the online setting. Merchandising and Recommendation - it is a normal practice in the merchandizing industry for the merchant to run creative expression for the product once the collection has been selected. For instance, merchants frequently exhibit the merchandise in some specific perspective such as with some accessories or against the backdrop of a specific environment. In online environment, these merchandising can be further enriched by applying the multi-media audio and visual aids. The environment and the decorations that are highlighted in the merchandising can become the basis for recommendations. The recommendations can be made available to the customer using buttons for recommendations, callouts, accessories or suggested use. In the digital world, recommendations can be based on a data mining methods so called collaborative filtering. In this method, recommendations are created by matching the buying patterns of previous customers to the buying patterns of the current customer based on their similarities. For example, Mr. Linton has bought19 books in the past; he can be compared to other customers who also bought those 19 books and what else those other customers have bought. Those other buying would become recommendations for Mr. Linton(Azahari, Raemah\& Yasmin, 2013; Stair \& Reynolds, 2010; Strauss \& Frost, 2009; Hanson \&Kalyanam, 2007; Kalyanam\& McIntyre, 2002; Poon \& Joseph, 2001; Smith \& Brynjolfsson, 2001).

\subsection{Price Strategy}

Now the focus of our argument is on the digital pricing methods, in particular to those that are considerably new including: Dynamic pricing - refers to as price change on regular basis due to meeting the characteristics and needs of individual customers and conditions. Forward auction sometimes refers to as English auction which has been popularized by eBay. In this technique the seller places an item for online auction. The item is on auction over a pre-specified time frame. The seller may or may not require to setting a minimum reserve price. The interested buyers bid on the item until the auction closes. Reverse auction- is about an exchange arrangement whereby the potential buyers offer the price they are willing to pay for particular items at the purchasing agent's Web site, and sellers have the right either to accept or reject the offer price (Azahari, Raemah\& Yasmin, 2013; Strauss \& Frost, 2009; Kalyanam \& McIntyre, 2002; Smith \& Brynjolfsson, 2001).

\subsection{Promotion Strategy}

The discussion on promotion techniques will include those that are substantially new such as: Banner $a d$ - is a rectangular space appearing on a Web site. Which allows the user to click-through to the advertiser's Web site. The owner paid for the advertisement. Sponsored Links - it is a combination of editorial content and advertising on a Web site. The owner pays for space and developed content that 
attract to the publisher's viewers. E-mail- is an Internet-based direct marketing. Given database of potential clients e-mail messages can be highly targeted and marketing campaigns can depend on "opt-in" or "permission marketing" to make sure that respondents do not get unsolicited message. Additionally, beside text, emails can also include video, audio and web pages. Viral marketingequivalent to online word-of-mouth or word-of-mouse, which take place when individuals forward email to coworkers, friends, family members, and others on their e-mail lists. E- coupons- equivalent to traditional coupons, but Internet users' "point and clip" these electronic coupons (Azahari, Raemah \& Yasmin, 2013; Strauss \& Frost, 2009; Hanson \&Kalyanam, 2007; Kalyanam\& McIntyre, 2002; Smith \& Brynjolfsson, 2001).

\subsection{Place (Distribution Channel) Strategy}

The discussion on place or distribution channel strategy will include the substantially new elements including: Remote Hosting- utilize a technology called "remote merchant hosting" the portal can host a mirror image of the site. Sellers can rent space on these shopping sections and the portal take the purchase order and forward the purchase order to the sellers. Affiliates- is a link to an e-tailer's Web site, put in by companies to get a commission on all purchases by referred buyers (Azahari, Raemah \& Yasmin, 2013; Strauss \& Frost, 2009; Hanson \& Kalyanam, 2007; Smith \&Brynjolfsson, 2001).

\subsection{Physical Environment Strategy}

Even if the bigger part of what the shopper is paying for is intangible almost all services include some physical components. For example a beauty salon would provide their clients with a completed hair makeover and an insurance agency would provide their clients some form of printed material. By definition, even though if the material is not physically printed (in the case of PDFs) they still get a "physical product". The location of the service delivery also takes on significance. To the customer the comfortable level and attractiveness of a service location may make a lot of difference to them. To new customers which will make them return, a tranquil and relaxing environment with thoughtful comfort measures may provide a sense of security (Professional Academy, 2018; Martin, 2014).

\subsection{Process Strategy}

So how the service is delivered is once again part of what the buyer is paying for normally the delivery of your service is done with the buyer present. The processes involved in the activity require special mention and attention since the delivery of your service needs to strike a balance between customization and standardization. For the service provider the process needs to be clearly welldefined. At any time and on any day this basic process should guarantee the same level of service delivery to every buyer. Within this process, there should be defined areas where a buyer inclination can be accommodated to provide a unique experience (Professional Academy, 2018; Martin, 2014).

\subsection{People Strategy}

All companies are reliant on the people who run them from front line employees to the Managing Director. Because they are as much a part of your business offering as the products or services you are offering. Therefore, having the right people at the right time is indispensable. In fact, it is an exceptionally important component of the E-marketing mix. The person delivering the service is not unique from the service itself. For instance, if a rude waiter is encountered when dining at a restaurant, the entire experience will be regarded as bad service. This is the reason why many companies invest in hiring the right person to fill-in their service role and then making efforts to find or train people to fit this definition (Professional Academy, 2018; Martin, 2014).

\subsection{Site Design Strategy}

For a company or an individual engaged in online business, a well design and appealing website can be considered as a powerful online portfolio. In fact, a website is an online identity of a company or of an individual involved in online business. Therefore, a well-designed, easy to navigate and search engine friendly website will obviously rank high in search engine resulting in more traffic to the website. The task connected with the website is to represent a company, sell company's brand name, draw more visitors, stimulate more sale, create more business leads and finally, help to gain more return on investment. In this era of advanced technology, electronic commerce has highly dominated the business practice. Additionally, due to easy accessibility and affordability of the Internet, people are running after it and making a lot of money at the comfort of their home. What is vital for our 
business is, to prepare a website that is well-designed, easy to navigate, attractive, good content, highly usable, full of relevant information and functionalities and are capable of retaining visitors for long and make them revisit the website again (Azahari, Raemah \& Yasmin, 2013; Stair \& Reynolds, 2010; Strauss \& Frost, 2009; Hanson \& Kalyanam, 2007; Kalyanam \& McIntyre, 2002; Smith \& Brynjolfsson, 2001).

\subsection{Security Strategy}

Along with personalization and privacy a related concern is with the Security of the web site itself. Whether someone can intercept the transaction and the credit card information and how easy it would be for a hacker to enter the web site are specific issues of concern. Sites address these issues with a security policy that addresses among other issues including: (1) what technology is being used (2)what aspects of the site and the transaction are secure and (3) if there is a security breach what the liability of the client is (Azahari, Raemah \& Yasmin, 2013; Kalyanam \& McIntyre, 2002 \& 2001; Smith \& Brynjolfsson, 2001).

\subsection{Sales Promotion Strategy}

This particular strategy has been widely applied in traditional marketing strategy. It is a strategy for immediate sales objectives in terms of quantity. Here, e-marketer's duty is to discover new tactics and new prospects for developing an effective promotion plan. Furthermore, e-marketer should to keep abreast with the newest internet technologies and applications (Professional Academy, 2018; Martin, 2014).

\subsection{Personalization Strategy}

Personalization refers to methods of individualizing an impersonal computer networked environment such as web sites that greet users by their name, providing personalized information. In another word, personalization in the digital world is a term use to imply any aspect of a website that is tailored individually in response to a returning customer. Typically users register with a site and create a profile and when the users return they only shown the information that they signed up for or find relevant. Compared to what a traditional storekeeper could achieve personalization on the website can be widespread. For example, personalization at Amazon.com takes place in the form of personalized book recommendations for well over 30 million shoppers (Azahari, Raemah \& Yasmin, 2013; Strauss \& Frost, 2009; Hanson \& Kalyanam, 2007; Kalyanam \& McIntyre, 2002 \& 2001; Hagen, Howe, \& Berman, 1998; Smith \& Brynjolfsson, 2001).

\subsection{Privacy Strategy}

A much debate topic such as the issue of the Warren and Brandeis concept of a right to be left alone. Often referred to as the seclusion theory; access control, which places its emphasis on laws and standards that enable persons to reasonably regulate the information that they are giving up. And autonomy that identifies private matters such as those necessary for a person to make life decisions. A typical privacy policy addresses what information is being collected and how it will be used and whether the information will be sold or shared with third parties and if so in what context (Azahari, Raemah \& Yasmin, 2013; Kalyanam\& McIntyre, 2002 \& 2001; Smith \& Brynjolfsson, 2001).

\subsection{Customer Service Strategy}

In this section we will focus our discussion on those service techniques that are substantially new including: Frequently Asked Questions (FAQ's) and Help Desks refers to link which leads to a help desk or a support page that provides users with links to specific customer support tools. A very common customer support tool is a frequently asked questions (FAQ) list. This list is usually reflective of the most common types of customer support issues. Chat room is a virtual space where Internet users can communicate with each other in real time using special software. E-mail Response Management is an automated response management system which responded instantly with an acknowledgement or thank you for the sender's inbound e-mail inquiry (Azahari, Raemah\& Yasmin, 2013; Strauss \& Frost, 2009; Kalyanam \& McIntyre, 2002; Smith \& Brynjolfsson, 2001).

\subsection{Community Strategy}

In term of an e-marketing tool, "community" means getting customers to interact with one another in a way that increases the benefits of coming to the sponsor's web site. A virtual community is also a location on the Internet where people communicate with each other. For example, chat rooms where 
individuals discuss specific automobiles, bonds, or sell and buy goods and services through auctions like eBayare all of virtual communities. Internet technologies have facilitated, in a very cost effective manner, the building of communities that are at the same time very narrow in terms of their focus while geographically broad in terms of their reach. In some cases the drive of the communication is to perform transaction as in the case of an online auction or a gift registry (Azahari, Raemah \& Yasmin, 2013; Strauss \& Frost, 2009; Hanson \& Kalyanam, 2007; Kalyanam \& McIntyre, 2002; Smith \& Brynjolfsson, 2001).

\section{Competitive Advantage}

Technology development has affected the way businesses function. First, it has changed the industry structures as well as changing the degree of competitiveness. Second, technology has generated a competitive advantage (CA) for the businesses which have implemented ICTs in their business activities or operations (Ongori \& Migiro, 2010).Porter (1986)describes competitive advantage as a direct consequence of the strategies executed by a company intended for adding value to customers. In a study performed by Ahmad, Ahmad, \&Nyager (2009), their findings had reinforced the dominant influence of technology strategy in achieving competitive advantage. Therefore, current study aims at exploring whether the adoption of e-marketing strategy really influences the competitive advantage of businesses. Based on the literature reviewed, a research framework is developed to explore the relationship between the various constructs in E-marketing (Independent variable) and the Competitive advantage (dependent variable). The research framework is shown in Fig 2. The model consists of fourteen independent variables namely: $(4 \mathrm{Ps}+3 \mathrm{Ps})+\mathrm{S} 3 \mathrm{P} 2 \mathrm{C} 2$. The dependent variable is $\mathrm{CA}$.

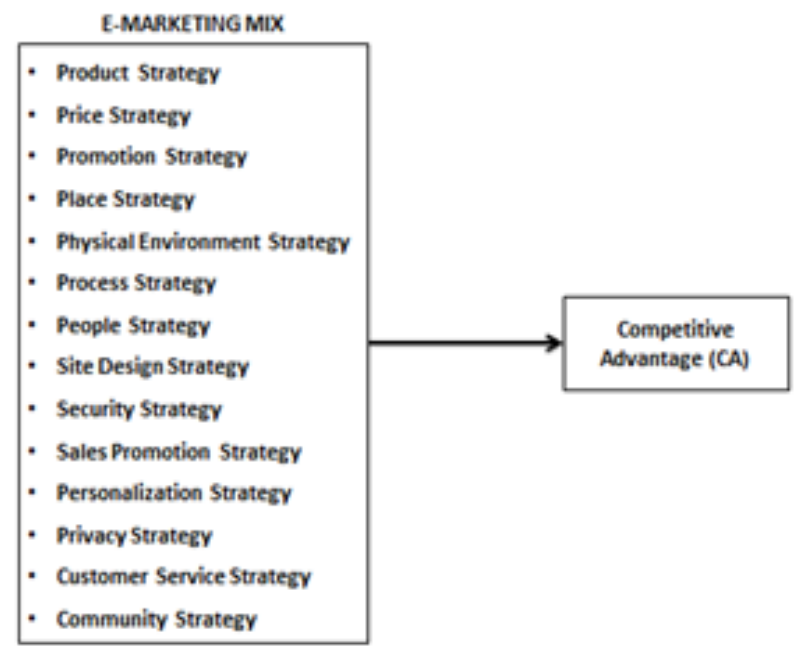

Figure2. The research framework of E-marketing strategy and competitive advantage

\section{CONCLUSION AND FUtURE RESEARCH}

Current study tries to offer some valuable insight into the relationship between E-marketing strategy and competitive advantage. Here, the researchers discuss the major elements contributing to the success of E-marketing. In specific, the researchers proposed that any newly formed businesses or existing businesses should prudently study and examine the e-marketing elements before making any investment decisions in business activities. Therefore, it is imperative that entrepreneurs looking for expert guidance regarding any concerns and questions before making any commitment in any type business models. A primary limitation of this study is that the E-marketing mix framework has yet to be validated as a "valid" framework. Thus, this is only a preliminary study and should be regarded as exploratory. This suggests that the first line of empirical research might be to validate this particular framework and categorization. Such an empirical validation of classification could be done with experts in the form of knowledgeable E-marketing managers or successful e-business entrepreneurs. It is hoped that this study would not only increase the entrepreneurs understanding of E-marketing, but also generate more interest in this type of business model.

\section{REFERENCES}

[1] Ahmad, A. Ahmad, H. \& Nyager, S. (2009). Technology Strategy and Competitiveness in Developing Nations: Exploratory Evidence from Nigerian Telecommunication Market. Journal of International Business and Entrepreneurship. Vol.14 no.1 pp.1-16. 
[2] Azahari, J., Raemah, A. H., \& Yasmin, Y. (Dec. 2013). Developing Malaysian Micro Entrepreneur Through E-Business. MARA Innovation Journal, Vol. 2 Issue 02. ISSN: 2289-2818.

[3] Azahari, J., \& Abd. Razak, M.Y. (2010). Promoting entrepreneurship through franchising: Visiting the process to franchising a business and the process to purchase a franchise, and the factors contributing to the success and failure of franchise business, Proceeding - The First Seminar On: Entrepreneurship and Societal Development in ASEAN (ISE-SODA 2010), Langkawi, Kedah, Malaysia.

[4] Hanson, W.A., \&Kalyanam, K. (2007).Internet Marketing \& e-Commerce, International Student Edition, Thomson-Southwestern, OH.45040, USA.

[5] Kalyanam, K., \& McIntyre, S. (2001). “The Role of Reputation In Online Auction Markets," Working Paper, Leavey School of Business, Santa Clara University.

[6] Kalyanam, K., \& McIntyre, S. (2002). The E-Marketing Mix: A Contribution of the E-Tailing Wars, Department of Marketing, Leavey School of Business, Santa Clara University, Santa Clara, CA 95053.

[7] Kotler, P., \& Armstrong, G. (2010).Principles of Marketing, Thirteenth Edition-Global Edition, Pearson Education, Inc., Upper Saddle River, NJ. 07458.

[8] Martin (2014).7Ps of marketing | Additional elements of marketing mix. Retrieved October 24, 2018, from: https://www.cleverism.com/7ps-additional-aspects-marketing-mix/

[9] Ongori, H. \&Migiro, S. O. (2010). Information and communication technologies adoption in SMEs: A Literature Review. Journal of Chinese and Entrepreneurship, vol.2 no.1, pp. 93-104.

[10] Poon, S., \& Joseph, M. (2001). A preliminary study of product nature and electronic Commerce, Marketing Intelligence \& Planning, Vol. 19(7): pp. 493-500.

[11] Porter, M. E. (1986). Competition in global industries: A conceptual framework (Ed.), competition in global industries. Harvard Business School Press: Boston, MA.

[12] Professional Academy (2018).Marketing theories - The marketing mix - From 4PS to 7PS. Retrieved October 24, 2018, from: https://www.professionalacademy.com/blogs-and-advice/marketing-theories--the-marketing-mix---from-4-p-s-to-7-p-s.

[13] Smith, M.D., \&Brynjolfsson, E. (2001).Consumer Decision-Making at an Internet Shopbot, MIT Sloan School of Management Working Paper No. 4206-01.

[14] Stair, R., \& Reynolds, G. (2010).Information Systems, Ninth Edition/International Edition, Course Technology, Cengage Learning, ISBN:13:978-0-324-78166-3.

[15] Strauss, J., \& Frost, R. (2009).E-Marketing, $5^{\text {th }}$ Edition, Pearson International Edition, Pearson Education, Inc., NJ, 07458.

[16] United States Department of Commerce (1996).Statistical abstract of the United States: 1996. Retrieved October 24, 2018, from:https://www.census.gov/library/publications/1996/compendia/statab/116ed.html

\section{AUTHOR'S BIOGRAPHY}

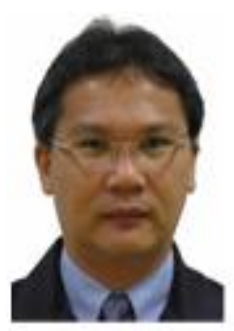

Professor Dr. Azahari Jamaludin is a Deputy Vice Chancellor (Academic and Industrial), Geomatika University College and Dean of IQRA Business School. He obtained a Doctor of Business Administration (DBA) from Northern University of Malaysia, MBA from National University of Malaysia, and Chartered Islamic Finance Professional from International Centre for Education in Islamic Finance, BBA in Marketing and Economics from Eastern Michigan University, Michigan, U.S.A., and Diploma in Planting Industry Management from Universiti Teknologi MARA, Malaysia. He is a member of the Chartered Institute of Islamic Finance Professionals. Dr. Azahari has jointly published 6 books, 8 modules and more than 40 articles in international journals and international conferences. His current research interests include organization development \& change, strategic management, and Islamic finance.

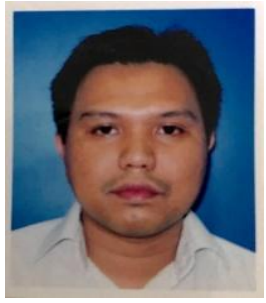

Mr. Hanafia Huridi joined UniKl Business School, formerly known as International School of Entrepreneurship (ISE) as a founding academician in 2010. Since then he has been served as Head of Section of Student Development, Head of Section of Campus Lifestyles, Head of Section of Industrial Linkages as well Head of Section of Economics. He has 12 years teaching experience in both economics and international business subjects and was served various institutions like University of Malaya and Management and Science University, Malaysia. Mr. Hanafia earned his Bachelor degree and Master degree in Applied Economics and Economics Development from University of Malaya. Currently, his research interests are economics, marketing, 
international business, strategic management, small and medium enterprise as well as export performance.

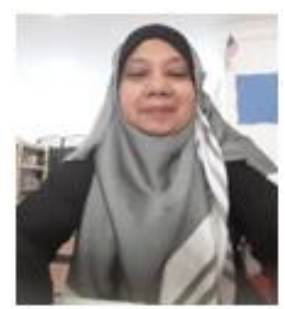

Professor Dr. Nor Yasmin binti Jamaludin is a Deputy Vice Chancellor Corporate \& Business Linkages. She obtained her Bachelor of TESL from University Putera and Master in Language Management and Teaching from University of Bristol, United Kingdom. Business School. She is currently pursuing another doctoral degree which is Doctor of Business Administration with Segi University, Kuala Lumpur. She has presented papers in conferences and has been involved in the areas of management for almost 25 years and she has successfully re-build a non performing company to a greater heights. Her current research interests include strategic management\& change, corporate governance and organization behaviour.

Citation: Azahari Jamaludin, et.al. "The Relationship between E-Marketing Strategy and Competitive Advantage: A Conceptual Framework" International Journal of Managerial Studies and Research (IJMSR), vol 6, no. 12, 2018, pp. 19-25. doi: http://dx.doi.org/10.20431/2349-0349.0612003.

Copyright: (C) 2018 Authors. This is an open-access article distributed under the terms of the Creative Commons Attribution License, which permits unrestricted use, distribution, and reproduction in any medium, provided the original author and source are credited. 